\title{
Non-royal Nubian Clothing Representations DURING THE NEW KINGDOM AND THE KUSHITES TWENTY- FIFTH DYNASTY
}

\section{Ahmad Ebied \\ Faculty of TOURISM AND Hotels, SOUth Valley UNIVERSity, LUXor BRanch, EGYPT}

\section{TAMER FAHIM \\ FACULTY OF TOURISM AND HOTELS, FAYOUM UNIVERSITY, EgYPT}

\begin{abstract}
There are interconnections between Egypt and Nubia since the Predynastic Period. The non-royal Nubians- as soldiers, servants, officials- were represented in the art of the New Kingdom in various artistic media. In c.750 BC the Kushites succeeded in invading Egypt and founding the Twenty-fifth Dynasty (c.750-664 BC). The non-royal Kushites adapted traditional non-royal Egyptian clothing and added some new elements to it. The authors here introduce a comparative study between the clothing of these non-royal individuals in the New Kingdom and Kushites Twenty-Fifth Dynasty in art. The New Kingdom art introduces Nubians wearing Egyptian clothing with remarkable Nubian features, while the Twenty-fifth Dynasty art represents Kushites wearing all Egyptian clothing from the Old, Middle and New Kingdoms as a kind of revivalism and adapting some Kushites elements; that misleads scholars to identify this new trend. The authors conclude that New Kingdom Egyptian artists in all representations marked non-royal Nubians with their own clothing, some of these Nubian clothing continued to be utilized by non-royal Kushites to keep their ethnic identity.
\end{abstract}

Keywords: Clothing, Kushites Twenty-Fifth Dynasty, New Kingdom, Non-royal Nubians, Non-royal Kushites. 


\section{INTRODUCTION}

The Nubians played significant roles in Egypt's history from the early beginnings. For instance, some Nubians were high officials in Egypt`s administration (e.g., physicians, magicians, farmers, workers and priests) during the New Kingdom, ${ }^{1}$ in spite of that Nubia was under the Egyptian hegemony. ${ }^{2}$ Nubian during New Kingdom possessed extraordinary positions. ${ }^{3}$ This is clear from statues and tombs whose belong to them. Likewise, they are depicted as tribute providers in many Egyptian depictions. ${ }^{4}$ Egyptians depicted Nubians in different roles before the Twenty-fifth Dynasty. Nubians were essential elements in Egypt`s military forces throughout its history; ${ }^{5}$ they held these military positions in an extraordinary number and with their ethnic dress such as leather loincloth, broad sashes. Additionally, they were represented as attribute providers wearing their distinctive leather loincloth with broad and long sash that hangs down over the loincloth.

Nubian clothing can be tracked down by shedding light on their artistic depictions in New Kingdom Egyptian art (e.g., leather loincloth, apron, broad sashes), and then the authors will compare these clothing with others (e.g., cloaks and bag-tunics) in the Twenty-fifth Dynasty for Kushites such as to know which continued and which did not or which could be considered innovation.

We will review past works as a starting point and examine the clothing of Nubian in general before the Twenty-fifth Dynasty as soldiers and officials or tribute offered to identity the Nubian style clothing before Kushites Dynasty, which advocates a nuanced understanding that necessitates a broad investigation, including both royal and individual representations as were record of the Twenty-fifth Dynasty.

\footnotetext{
${ }^{1}$ Liszka, k., (2013). Foreigners, Pharaonic Egypt, In B. Rogers (ed.), the Encyclopedia of Ancient History, London, pp. 2710- 2713.

${ }^{2}$ Morkot, R.G. (1987). Studies in New Kingdom Nubia 1: Politics, Economics and Ideology: Egyptian imperialism in Nubia, Wepwawet 3, pp. 29- 49.

${ }^{3}$ Nubia has been affiliated to Egypt for a long time, Egyptian kings struggled a lot to avoid Nubian conquered and chaotic, but we should keep in our mind that the relationship between Egypt and Nubia changed during New Kingdom proof of this the high positions of Nubians in royal court.

${ }^{4}$ Depictions of Nubian tribute with their distinctive clothing and costumes, tomb of Huy, $18^{\text {th }}$ Dynasty, New Kingdom, Schneider, T., (2010). 'Foreigners', In W. Wendrich (ed.), Egypt: Archaeological evidence and Cultural Contexts Egyptian Archaeology, London, pp. 143-63.

${ }^{5}$ Ibid
} 


\section{Clothing of Nubians in the NeW Kingdom}

The ancient Egyptians represented Nubians in a traditional way, ${ }^{6}$ where they typically delineated with dark skin, curly hair wig and thick fleshy lips while some other individuals where portrayed in a distinctive way. Below we'll present the main features of Nubian clothing in New Kingdom art (e.g., leather loincloth, apron, broad sash).

\section{LEATHER LOINCLOTH}

Loincloth is considered one of the simplest dresses; wrapped around the waist with a hanged end between the legs. ${ }^{7}$ We here focus on the leather loincloth which was a piece of leather cut to form a network of slits; it became popular during the New Kingdom and was only worn by low status Nubian men such as soldiers, ${ }^{8}$ (Fig.1) and in the rows of tribute providers ${ }^{9}$ (Fig. 2) for example in Rekhmire tomb (TT 100). ${ }^{10}$ The Nubians wear two types of leather loincloth however some Egyptians were depicted wearing the same dress in the New Kingdom. (Figs. 3, 4)

The originality of the leather loincloth whether from Nubia or Egypt is still debated. We are here investigating its first appearance and development from the beginning. There are no Old and Middle Kingdom depictions of leather loincloth.

Our first evidence comes from the New Kingdom:

\footnotetext{
${ }^{6}$ Bresciani, E., (1997). Foreigners. In. S. Donadoni. (ed.), The Egyptians, Chicago, pp. 221- 53.

${ }^{7}$ Loincloth has two kinds of loincloth, which was known from Old Kingdom, the cloth loincloth and leather loincloth and the latter is the favorable costume to the Nubians, Vogelsang-Eastwood, G., (1993). Egyptian Pharaonic Clothing, pp. 10- 11, Petrie recorded that the leather loincloth was common in the pan-graves at nearby Dispolisparva, Petrie, W.M.F., (1901). Dispolis Parva; The Cemeteries of Abadiyah and $\mathrm{Hu}, 1899$, London, p. 51.

${ }^{8}$ Vogelsang- Eastwood, (1993). op. cit, p. 16, Fig 2: 16.

${ }^{9}$ Reliefs from tomb of Huy, who is an Egyptian official who lived during the reign of King Tutankhamen (1336-1327 BC), P. M, I, 1960, p. 26; Marilina, B., (2010). Virtual Environments and Web Community in Archaeology: Theban Tomb 14 as Case Study, In: Galina A. Belova and Sergej V. Ivanov (Eds.). Achievements and Problems of Modern Egyptology: Proceedings of the International Conference Held in Moscow on September 29 October 2, 2009, Moscow: Russian Academy of Sciences, Center for Egyptological Studies, pp. 40- 48.

${ }^{10}$ P. M, I, pp. 206- 214; Davies, N de Garis., (1943). Tomb of Rekh-mi Re at Thebes, New York; Davies Norman \& Nina, (1935). Paintings from the Tomb of Rekh-mi-Re' at Thebes, PMMA 10, New York.
} 
- Mahirpre tomb (KV36) provides a huge amount of leather loincloth ${ }^{11}$ which probably originated from Syria. ${ }^{12}$

- Another group of leather loincloth was found in Balabish. ${ }^{13}$ The New Kingdom art reveals evidence of the representations of this dress in some tomb scenes. ${ }^{14}$

- For instance, there is a scene in the tomb of Amenhotep-Huy or Huy (TT 40) ${ }^{15}$ which portraying Nubian wearing the leather loincloth. This type of leather loincloth is deeply rooted in Nubian Culture where it appeared in the C-group graves in the Adindan cemeteries ca. $2300-1600$ B.C. ${ }^{16}$ which may indicate that the appearance of the leather loincloth was earlier than the Egyptian.

Vogelsang confirmed that the leather loincloth was the favorable cloth to Nubians in Egypt. ${ }^{17}$ The artistic representation of Amenophis II wearing leather loincloth in Ken-Amūn tomb (TT 93) indicates that this dress characteristic feature of Nubian identity and representation of the king as a victory over Nubia and declare his domination over Nubia (Fig. 5). Maybe this cloth is earlier to influence of the Hyksos during the $2^{\text {nd }}$ Intermediate Period. ${ }^{18}$

Concerning its function, there are many opinions said that the loincloth may have been worn by priests only during the opening of the mouth ritual, or pointed to it as a part of military costume, ${ }^{19}$ or the function of this dress was unclear.

\footnotetext{
${ }^{11}$ The most widely published leather loincloth came from tomb of Mahirpre which was excavated by Carter in 1902, some of them in Boston Museum, See, Carter, H. (1903). Rapport on the General Work done in the South Inspectorate, ASAE IV, pp. 43- 50.

${ }^{12}$ Ibid

${ }^{13}$ These leather loincloths are made by simply cutting to shape an animal skin with or without the hair, Wainwright, G.A. (1920). Balabish, Egypt Exploration Society, London, pp. 28- 29.

${ }^{14}$ There are many depictions of Egyptian workers with leather loincloth such as Rekhmire and Menna tombs, Vogelsang-Eastwood, G., op.cit, 1993, Figs 2:12, 13, 14, 15.

${ }^{15}$ It was located at Qurnet Mura'i. This is one of very few tombs datable with certainty to the reign of Tutankhamen. The owner is called Amenhotep, but prefers to be called the most familiar diminutive of Huy.

${ }^{16}$ Bianchi, R., Daily Life of the Nubians, p. 77.

${ }^{17}$ Vogelsang-Eastwood, G., op.cit, p. 29; In addition to the leather garments found in Egyptian context, See, Adams, W.Y., (1977). Nubia: Corridor to Africa, London; William, B., (1983). C-group, Pan-Grave and Kerma Remains at Adindan Cemeteries T, K, V, Chicago, p. 65.

${ }^{18}$ Hays, W.C., (1959). The Scepter of Egypt, II, New York, p. 19

${ }^{19}$ Jequier, G., (1910). "Un Piéce du Costume Militaire", RE 32, pp.173- 174.
} 
It would seem that the origin of the leather loincloth lies in Nubia. For many reasons:

- It is introduced by the Nubian mercenaries during Middle Kingdom (Fig. 6).

- Egyptian did not prefer the leather in their costumes, May it is not fit the hot weather, and also, we can see the majority of extracted loincloth from tombs for Nubians.

- The representation of Amenhotep II guise of Nubian warrior to show his authority over that land. ${ }^{20}$

So, we can conclude that, it probably arrived in Egypt sometime during the early Middle Kingdom or slightly earlier and then became popular during the New Kingdom, being worn only by men, including laborers, sailors and soldiers, as well as a member of the court, with Nubian connections. So, the attribution of leather loincloth to Nubian based on the garments found in Nubian graves and also through the Egyptian tombs of Nubian high officials in New Kingdom, like Mahirpre.

\section{NUbian APRON}

The apron ${ }^{21}$ is an Egyptian item of cloth was worn under the kilts from Old Kingdom. It also was worn over kilts as a decoration items as long strips or a starched triangle for individuals from the Old Kingdom to the Late Period, and the Nubians adopted this item and modified it to express their ethnicity. They favored two kinds of apron: one as a separate item with a long sash and the other as apron with color stripes worn over their kilt. Nubians in Egyptian depictions predating the Twenty-fifth Dynasty wear an apron as a decorative item over another cloth (Fig. 7). ${ }^{22}$

The basic construction of the apron is simple, consisting of one or more bits of fabric connected to a belt, scarf or band which is affixed around the waist. There are not any Pharaonic Egyptian aprons, yet we have case

\footnotetext{
${ }^{20}$ Statue of King Amenhotep II, guise of Nubian warrior with leather loincloth to show his authority on that land, tomb of Ken-Amun, Thebes, Vogelsang-Eastwood, G., (1993). op.cit, p. 30, fig 2: 17.

${ }^{21}$ Apron is a separate item of cloth; it is worn under the kilt to cover the genital region or over the kilt as a decorated item, for more information.

${ }^{22}$ Two Nubian archers depict wearing apron over kilt first scene from tomb of St-Ka, $1^{\text {st }}$ intermediate period, he is wearing short kilt with green apron, while the other scene depicts wearing short sash and apron from Ankhtify tomb, $1^{\text {st }}$ intermediate period, Fischer, H.G., (1961). "The Nubians Mernceries at Gebelein during $1^{\text {st }}$ intermediate", Kush IX, pp.44- 80.
} 
from Qasr Ibrim and Gebel Adda in Nubia from the Meroitic period, ${ }^{23}$ which reflects the development of the Nubian apron. There is a relationship between the wearing of scalloped-edged apron during Middle Kingdom by men of Nubian extraction. ${ }^{24}$ A number of men depicted in the battle scenes of the $11^{\text {th }}$ Dynasty in tomb of Antef were actually Nubian mercenaries and their aprons were some form of codpiece that covered the genital region (Fig. 8).

\section{BAg-TUNIC OF BROAD SASH}

Another item of Nubian clothing that appears before the Twenty-fifth Dynasty is the broad sash of bag-tunic ${ }^{25}$ with geometrical length sash wrapped around the waist like the belt then hangs down (Fig. 9). Nubian tribute-bearers in Huy's tomb wear a short bag-tunic with short sleeves and long sash-kilt. The long sash with rosette decorations is a notable feature of the Nubian costumes. It begins as a diagonal strap over left shoulder, then wraps around the waist as belt before hanging down as a frontal tassel.

\section{Clothing of Non-Royal Kushites in Twenty-FifTh Dynasty}

When Russmann writes: ${ }^{26}$

"There was indeed a large stock of representations of Kushites, but, almost without exception, they were pictures of enemies, servile emissaries, and servants, usually unsympathetically rendered and often little more than caricatures".

She overlooked Nubians who occupied the high position, especially during the New Kingdom. These individuals dressed like kings and queens; for example, statues of two Nubian women named Tuty and Mi, dating to the Amarna period, show them wearing aristocratic female dress consisting of a full-length bag-tunic with shawl (Fig. 10). The situation changed completely after the Kushites invaded Egypt. At this point many Kushites assumed Egyptian costumes, and in doing so they present

\footnotetext{
${ }^{23}$ Single aprons form Gebel Adda, precisely from tomb of adult male in C. III in grave (622. AI) (Rom, u 62, Royal Ontario museum, Toronto). Meroitic Apron is based on the Gebel Adda example, the same method of the construction was apparently used for the pieces from Qasr Ibrim, according to Vogelsang, this Apron were made out of two panels of shaped cotton sewn together down the middle, Vogelsang-Eastwood, G., op.cit, p. 33, fig 3:2.

${ }^{24}$ Fischer, H. G., op. cit, p. 68.

${ }^{25}$ Bag-Tunic was known at the end of Middle Kingdom and it became more popular during the New Kingdom for Egyptian Kings and Individuals, Vogelsang- Eastwood, G., op.cit, pp.131- 132, fig 8:1, 2 .

${ }^{26}$ Russmann, Egyptian Sculpture, p. 167.
} 
evidence for the relationship between Egyptian and Kushites in their costumes.

Reliefs of Mentuemhat tomb (TT 34) ${ }^{27}$ provide us with details of the costumes worn by Kushites high officials and also the high priests of Amun. Initially, the majority of the costumes under examination here may seem to indicate an adherence to Egyptian costumes, expressing a renaissance or revivalism of costumes from the Old to New Kingdoms. ${ }^{28}$ Mentuemhat is depicted wearing the royal kilt with apron after the fashion of the Old Kingdom rulers (Fig. 11). He also appears with the wraparound cloak (Fig. 12), imitating in this costume the individuals of the Middle Kingdom (Fig. 13).

Among his costumes, too, is that of a priest, consisting of a collar necklace and a leopard skin vestment with a diagonal upper border and a shoulder knot of an archaic type ${ }^{29}$ this is marked with dotted-rosettes, traces of which are still visible. The leopard head and many of the rosettes on Mentuemhat garb are incomplete, and the back two-thirds of his skirt have been left without pleats (Fig.14). ${ }^{30}$ This dotted-rosette decorative pattern is repeated on a statue of Mentuemhat ${ }^{31}$ (Fig. 15), in which he appears wearing a knotted priestly costume. Notably, this decoration is reminiscent of the rosette on Tantamani's cloak. ${ }^{32}$ (Fig. 16)

The reliefs of another high-ranking individual, Harwa, ${ }^{33}$ reveal more about Kushites private costumes. He appears in full-length bag-tunic with

\footnotetext{
${ }^{27} \mathrm{He}$ was the $4^{\text {th }}$ prophet of Amun at Thebes. He was son of Esptah, a Prophet of Amun and mayor of the city. He served during the reigns of Taharqa and Psamtik I, for more information See, Kitchen, A., (1986). The Third Intermediate Period in Egypt, 1100-650 B.C., pp. 390, 394-5, 397, 399- 400, 404, P. M, I, pp.56- 61, pl. XIX- XX.

${ }^{28}$ Tiradritti, Fr., (2008). Pharaonic Renaissance: Archaism and the Sense of History: Exhibition, Cankarjev Dom, Ljubljana, pp.49- 50; Josephson, J., (2001). “Archaism", In: D. Redford, ed., The Oxford Encyclopedia of Ancient Egypt, 1, Oxford, pp.109- 113.

${ }^{29}$ Relief of Mentuemhat is Exhibit in the Nelson-Atkins Museum of Art, Kansas City, Missouri, USA, for information See, Russmann, E., (1994). Relief Decoration in the Tomb of Men-tuemhat TT 34, JARCE 3, pp. 1- 19; Staehelin, E. (1966). "Unterschungen Zur Ägyptischen Tracht im Alten Reich", MÄS 8, Berlin, pp. 54- 5.

30 Russmann, E., (1997). "Mentuemhat Kushite Wife (Further Remarks on the Decoration of the Tomb of Mentuemhat, 2), JARCE 34, pp. 21- 39.

${ }^{31}$ Bothmer, V., (1960). Egyptian Sculpture of the Late Period, Brooklyn Museum, p.14, no.13, fig 29-31.

${ }^{32}$ Leahy, A., (2014). Kushites At Abydos: The Royal Family And Beyond, In: Thebes in the First Millennium BC, (ed.) Elena Pischikova, Julia Budka, Kenneth Griffin, p. 68.

${ }^{33}$ Harwa lived at the beginning of the $25^{\text {th }}$ Dynasty and held one of the most important positions in the theocratic state of Amun of Thebes attaining the position of Grand Steward of the Divine Adoratrice, Tiradritti, F., (1998). Three years of researches in the Tomb of Harwa, Egyptian Archaeology 13, pp. 3- 6; Russmann, E., (1983). "Harwa as
} 
short sleeves, which has pointed out as a fashion of the late $18^{\text {th }}$ Dynasty revived under the Twenty-fifth. ${ }^{34}$ Another item of costume that he wore was the short closed kilt with lines of hieroglyphs. ${ }^{35}$ Like the costumes previously described, Harwa's are modeled on garments of the Egyptian Old and Middle Kingdom.

Kushites wore it in various styles and decorations, making it important to compare to is the last item of costumes, it is important to display all the possible styles of cloak from Old kingdom to New kingdom then, during $25^{\text {th }}$ dynasty, So that the authors try to originate the cloak whose were worn by Kushites during $25^{\text {th }}$ dynasty.

Initially, the 'cloak' was a large oblong, square, or rectangular piece of cloth, easily removable, extending below the waist and usually worn over other garments. ${ }^{36}$ There is a suggesting said that some of these garments depicted in Egyptian art could be blankets. Clearly, the cloak was an over-garment. Beyond this basic definition, the many types of cloaks in Egyptian art can be divided into two primary groups: wrap-around and knotted. ${ }^{37}$

Pekartror is shown wearing a transparent cloak that leaves his left shoulder free. ${ }^{38}$ (Fig. 17) The two upper corners of the cloth are knotted on his right shoulder, and the cloak is fringed on its right side. That side of Pekartror's body is visible because the cloak is open there. There is a fringe at the bottom of the garment, but it is not clear if it belongs to the cloak or to a kilt worn as an inner garment. This type of cloak is very

Precursor of Mentuemhat", In: H. De Meulenaere, L. Limme (Eds.), Artibus Aegypti. Studia in Honored Bernardi V. Bothmer a Collegis Amicis Discipulis Conscripta, Bruxelles, pp. 137-146., he had a lot of statues; British Museum EA 55306, British Museum EA 32555, Cairo JE 36930, Cairo JE 36711, Cairo JE 37386, Cairo JE 37377, Leipzig 8163.

${ }^{34}$ Bianchi, Robert S., (2004). Daily Life of the Nubians. Westport, Conn: Greenwood Press, pp. 207- 211; Kuentz, Ch., (1934). "Remarques Sûr les Statues de Harwa", BIFAO, XXXIV, pp. 143- 163.

${ }^{35}$ Russmann, E.R., (1983). op. cit, pp. 137-146; Tiradritti, F., (1999). The Importance and the Role of Harwa and his Tomb (TT 37) in the Egyptian History, Quaderni Ticinesi XXVIII, pp. 9- 23.

${ }^{36}$ Staehelin, E., "Mantel", L $L \ddot{A} 3$, pp. 1182-83

${ }^{37}$ Vogelsang- Eastwood, G., (1993). op.cit, pp. 159- 160.

${ }^{38}$ This stela is dated to the $25^{\text {th }}$ Dynasty from Abydos. It displays stylistic features more typical of Memphis than Abydos, Munro, P., (1973). Die Spätägyptischen Tötenstelen, Gluckstadt, p. 84. 
uncommon in Egyptian art. The author is aware of only one other representation of a very similar costume: the cloak of Iriketakana. ${ }^{39}$

Of this sculpture Leclant writes: "Too obese to wear a man's loincloth without looking ridiculous, this nobleman wears an unusual garment, a sort of smock with shoulder straps" ${ }^{40}$ But Bianchi gave a different description of Iriketakana's costume,${ }^{41}$ comparing it instead to the attire of Pekhor-En-Khonsu ${ }^{42}$ depicted on a fragment from his wooden sarcophagus. Here, a cloak wraps several times around the wearer's body.

Bianchi writes: "The fashion of wearing wraparound skirts in association with short sleeved garments very much resembling modern $\mathrm{T}$-shirts and wraparound fringed shawls gained currency in Egypt during this period". ${ }^{43}$

While this description may be appropriate for Pekhor-En-Khonsu, it does not properly describe Iriketakana's garment. Iriketakana wears a cloak knotted only on one side. Pekhor-En-Khonsu has a shawl wrapped around his body and slung over his back. Hallmann ${ }^{44}$ suggested that " by comparing Pekartror's cloak with Iriketakana's we find exactly the same very thin outer garment which is worn under the left armpit, knotted at the right shoulder, open on the right side and fringed on the right edge. "She further observes that the "Kushites tail" (fig. 18) is the primary distinguishing feature between the cloaks worn by these two men. ${ }^{45}$

If we want to examine the origin of this cloak, which was worn by Kushites during the Twenty-fifth Dynasty, we must compare this item with another Egyptian one (fig. 19, 19a). ${ }^{46}$ These examples demonstrate

\footnotetext{
${ }^{39} \mathrm{He}$ was high official during $25^{\text {th }}$ Dynasty whose statue was found in the Karnak Cachette in 1905.

${ }^{40}$ Leclant, J., (1976). "Kushites and Meroïtes: Iconography of the African Rulers in the Ancient Upper Nile," In, Jean Vercoutter et al., eds., The Image of the Black in Western Art, 1: From the Pharaohs to the fall of the Roman Empire, New York, p. 116.

${ }^{41}$ Bianchi, R., (2004). Daily Life of the Nubians, London, pp. 209- 211.

${ }^{42}$ Pekhor-En-Khonsu wearing a cloak wrapped several times around his body, M.M.A. 28.3.52, Winlock, E., (1928). “The Egyptian Expedition 1927-1928: The Museum's Excavations at Thebes", BMMA 23, pp. 3-28.

${ }^{43}$ Bianchi, R., (2004). op. cit, p. 209.

${ }^{44}$ Hallmann, A., (2007). The "Kushite Cloak" of Pekartror and Iriketakana: Novelty or Tradition, JARCE 43, pp. 15- 27.

${ }^{45}$ The so-called "Kushite tail" is found on many Kushite depictions, e.g., stela Louvre E.13073, Munro, Tötenstelen, pl. 28, fig. 101; and Cairo stela, Munro, Tötenstelen, pl. 27, fig. 99; we should stress that the "Kushite tail" which is noticeable on the depiction of Iriketakana is something different since it hangs from a fringe.

${ }^{46}$ Another relief for man with cloak on a stela in Egyptian Museum, Cairo JE 21972, Munro, P., Tötenstelen, pl. 29, 33, fig. 103, 120.
} 
that an unusual cloak-like garment was worn in the Twenty-fifth Dynasty. ${ }^{47}$ Similarities exist between this Kushite cloak and the pleated and fringed cloak worn by a group of priests in the tomb of Nakhtamun, but the Kushite cloaks are knotted at the two upper corners of the cloth on the right shoulder. ${ }^{48}$

Kushite and also Meroitic kings are known to wear similar cloaks. At El Kurru, the tomb of Tanuwetamun, last ruler of the Twenty-fifth Dynasty, shows him wearing a cloak with a knot at the right shoulder. A cloak worn by a Meroitic king depicted in reliefs at the temple in Musawwarat es Sufra, where open-sided cloaks with shoulder knots fringe also appear. ${ }^{49}$ The style and placement of the knots differ, however, between these royal examples and the private ones provided by Pekartror and Iriketakana. $^{50}$

In summary, the cloak of Pekartror is also very similar to those worn by the musicians on the temple wall from Kawa (fig. 20) and from stela JE 21972 and Meux 50b. A few parallels with Libyan and Hittite garments can be observed, but they are not significant enough to claim any stylistic influence of one culture upon the other.

Overall, after compare the so-called 'Kushite cloak' with Egyptian traditional cloak, we can conclude that the 'Kushite cloak' remarked with decoration and its method of tying, concerning its decoration was long fringe on a diagonally arranged on any side and the bottom, also the Kushite tail, which found on many Kushite depictions, and the method of tying of the Kushite cloak knotted at the two upper corners of the cloth on his right shoulder (but not all cloaks are knotted on the same side), all these remarkable features of this Kushite cloak, make the scholars pointed out that may this cloak as a kind of innovations of Kushites during Twenty-fifth Dynasty.

\section{CONCLUSIONS}

After viewing all the Kushites costumes that appeared during the Twentyfifth Dynasty, whether royal or individuals, it is clear that the costumes of

\footnotetext{
${ }^{47}$ Hallmann, A., (2007). op.cit, pp. 15- 27.

${ }^{48}$ Leahy commented on the methods of knotting the cloaks for Egyptians and she noticed their similarities to those worn by Libyans, Leahy M., (1988). Private Tomb Reliefs of the Late Period from Lower Egypt, I, PhD, Oxford, p. 230.

49 Török, L., (1997). op.cit, pp.160- 161; Wenig, S., (1993). "Die Darstellungen Untersuchung zu Ikonographie, Inhalt und Komposition der Reliefs", In Fritz Hintze, ed., Musawwarat Es Sufra. Der Löwentempel, vol. 1: Textband, Berlin, pp.74- 227, esp. 155-56, figs. 97-98.

${ }^{50}$ Hallmann, A., (2007). op.cit, p. 27.
} 
the Kushites passed through various stages associated directly to the political situation after the invasion of Egypt.

It is logical to begin the first phase of the Kushites after the invasion of Egypt by ensuring and interests the feelings of the Egyptians, so Kushites kings appears wearing all royal Egyptian costumes and they choose the Old Kingdom period as one of the most flourished period in Egyptian civilization to imitate and copy its style art, they want to send important message to Egyptian that they come to Egypt as legitimate kings to restore the lost Egyptian glorious, in this phase the Royal Egyptian Kilts and skirts with different styles were worn by Kushites kings, then we notice that the Kushites kings began gradually adding few Kushites features to their costumes.

They appeared through their statues and reliefs with composite costumes which consists of upper dress with clasp shoulder straps as a first consideration Kushites feature was add to the Egyptian traditional dress, then the kilt or length skirt, another Kushites features was add to their costumes, the tasseled cord, After the investigation became certainly its originality to the Kushites priests of God Amun at Kawa then it was moved by the Kushites princes who came to Egypt to the Egyptian priests of Amun at Thebes to become popular in the Kushites costumes during Twenty-fifth Dynasty.

It is notable that Kushites kings during Twenty-Fifth Dynasty not only imitate the Egyptian royal costumes, but also they wore the costumes of individuals during Old and Middle kingdom, may they want to satisfy all categories of people after invasion.

King Taharqa appear wearing feminine costumes as royal kilt was decorated with feather, this costume is look like costume of queen Tiye during the New Kingdom. Gradually the Kushites kings are add their ethnic features on their costumes, to maintain their origin and this is a clear in their keen to bury in their homeland. indicate the most popular costumes of Kushites royal women during Twenty-Fifth Dynasty, all these costumes of Kushites royal women were copied from Egyptian costumes, especially the god`s wives of Amun costumes during New kingdom, but certainly appearing of Amenirdis with priestly costume was a new innovation at that time, also the decorations of their costumes may reflected some innovations on their traditional costumes, such as knotted straps shoulder with remarkable knot, also the fox tail was as prominent features of Kushites decorations during Twenty-fifth Dynasty. 
The costumes of Kushites individuals during Twenty-fifth Dynasty that it indicates that Kushites individuals who came after invasion to Egypt and worked in high ranked position, they have stepped the same steps of their kings, that they appear wearing the identical Egyptian costumes which date in its style to Old and Middle Kingdom like kilts with apron under and the long skirt with traditional desertions, may be the cloak which knotted on one shoulder was the most prominent features of Kushites individuals costumes, and there are various efforts to originate this cloak, weather its originate to the Egyptian or it was considered a Kushites innovations, the whole costumes with decorations Reaffirms the overlap and complexity of the clothes between Egyptian and Kushites during $25^{\text {th }}$ dynasty.

Finally, the authors have to emphasize, the respect of the Kushites to the Egyptians which was proved by appearing with Egyptian costumes, but with some Kushites features, which were add deliberately on their costumes, this duplication appearance of Kushites represented a new tendency that, it combined between archaism or renaissance and the innovations in same time.

The Twenty-fifth Dynasty had every opportunity to precisely re-create the culture of Egypt and "pass" themselves as native Egyptians, but chose not to do so. Far from attempting to copy an Egyptian cultural system, the Kushites maintained certain relevant aspects of their own culture while incorporating aspects of Egyptian culture into a new, coherent system of succession.

They commissioned depictions of themselves that were very distinct from previous royal portrayals. They emphasized their distinctive African physiognomy and further distinguished themselves through various features added onto costumes. It became a clear phenomenon during the Twenty-fifth Dynasty for the Kushite rulers that this clothing gathered between ankle length garment and cloak then shawl, very ornate aprons with uraei fringes. This fastened cloak, however, does appear in the Middle Kingdom. For examples, individuals wear such a garment in scenes in the tomb of Ukh-Hotep. Here the cloak drapes over one shoulder (and upper arm) and hangs slightly shorter than the tunic worn underneath.

We can agree with Török when he suggested that the asymmetrically fastened cloak of Tantamani was introduced into ancient Egyptian society through female fashion during the reign of Amenhotep II; later, during the reign of Amenhotep III, it appeared as a male garment. Also Vogelsang 
pointed out that this garment, which she called the "knotted cloak," appeared as a new style of cloak during New Kingdom.

As is usual in changing fashion, this draped cloak transferred to kings during the New Kingdom; Amenhotep III is considered the first king to wear this type of cloak (Fig. 21). A serpentine statue depicts the king wearing a shawl draped over his left arm and a fringed tunic beneath.

\section{REFERNECES}

Adams, W.Y., (1977). Nubia: Corridor to Africa, London.

Bianchi, Robert S., (2004). Daily Life of the Nubians, Westport, Conn: Greenwood Press.

Bothmer, V., (1960). Egyptian Sculpture of the Late Period, Brooklyn Museum.

Bresciani, E., (1997). Foreigners. In. S. Donadoni. (ed.), The Egyptians, Chicago.

Carter, H. (1903). Rapport on the General Work done in the South Inspectorate, ASAE IV.

Davies Norman \& Nina, (1935). Paintings from the Tomb of Rekh-mi-Re' at Thebes, PMMA 10, New York .

Davies, N de Garis., (1943). Tomb of Rekh-mi Re at Thebes, New York.

Fischer, H.G., (1961). "The Nubians Mernceries at Gebelein during 1st intermediate", Kush IX.

Hallmann, A., (2007). The "Kushite Cloak" of Pekartror and Iriketakana: Novelty or Tradition, JARCE 43.

Hays, W.C., (1959). The Scepter of Egypt, II, New York.

Jequier, G., (1910). "Un Piéce du Costume Militaire", RE 32.

Josephson, J., (2001). "Archaism", In: D. Redford, ed., The Oxford Encyclopedia of Ancient Egypt, 1, Oxford.

Kitchen, A., (1986). The Third Intermediate Period in Egypt, 1100-650 B.C.

Kuentz, Ch., (1934). "Remarques Sûr les Statues de Harwa", BIFAO, XXXIV.

Leahy M., (1988). Private Tomb Reliefs of the Late Period from Lower Egypt, I, PhD, Oxford.

Leahy, A., (2014). Kushites At Abydos: The Royal Family And Beyond, In: Thebes in the First Millennium BC, (ed.) Elena Pischikova, Julia Budka, Kenneth Griffin.

Leclant, J., (1976). "Kushites and Meroïtes: Iconography of the African Rulers in the Ancient Upper Nile," In, Jean Vercoutter et al., eds., 
The Image of the Black in Western Art, 1: From the Pharaohs to the fall of the Roman Empire, New York.

Liszka, k., (2013). Foreigners, Pharaonic Egypt, In B. Rogers (ed.), the Encyclopedia of Ancient History, London.

Marilina, B., (2010). Virtual Environments and Web Community in Archaeology: Theban Tomb 14 as Case Study, In: Galina A. Belova and Sergej V. Ivanov (Eds.) Achievements and Problems of Modern Egyptology: Proceedings of the International Conference Held in Moscow on September 29 October 2, 2009, Moscow: Russian Academy of Sciences, Center for Egyptological Studies.

Morkot, R.G., (1987). Studies in New Kingdom Nubia 1: Politics, Economics and Ideology: Egyptian imperialism in Nubia, Wepwawet 3.

Munro, P., (1973). Die Spätägyptischen Tötenstelen, Gluckstadt.

P. M= Porter B. and R. Moss, (1960) Topographical Bibliography of Ancient Egyptian Hieroglyphic Texts, Relief and Paintings. Oxford.

Petrie, W.M.F., (1901). Dispolis Parva; The Cemeteries of Abadiyah and $\mathrm{Hu}, 1899$, London.

Russmann, E., (1983). "Harwa as Precursor of Mentuemhat", In: H. De Meulenaere, L. Limme (Eds.), Artibus Aegypti. Studia in Honored Bernardi V. Bothmer a Collegis Amicis Discipulis Conscripta, Bruxelles.

Russmann, E., (1994). Relief Decoration in the Tomb of Men-tuemhat TT 34, JARCE 3.

Russmann, E., (1997). "Mentuemhat Kushite Wife (Further Remarks on the Decoration of the Tomb of Mentuemhat, 2), JARCE 34.

Russmann, Egyptian Sculpture.

Schneider, T., (2010). 'Foreigners', In W. Wendrich (ed.), Egypt: Archaeological evidence and Cultural Contexts Egyptian Archaeology, London.

Staehelin, E. (1966). "Unterschungen Zur Ägyptischen Tracht im Alten Reich", MÄS 8, Berlin.

Staehelin, E., "Mantel", LÄ 3.

Tiradritti, F., (1998). Three years of researches in the Tomb of Harwa, Egyptian Archaeology 13.

Tiradritti, F., (1999). The Importance and the Role of Harwa and his Tomb (TT 37) in the Egyptian History, Quaderni Ticinesi XXVIII.

Tiradritti, Fr., (2008). Pharaonic Renaissance: Archaism and the Sense of History: Exhibition, Cankarjev Dom, Ljubljana.

Vogelsang-Eastwood, G., (1993). Egyptian Pharaonic Clothing.

Wainwright, G.A. (1920). Balabish, Egypt Exploration Society, London. 
Wenig, S., (1993). "Die Darstellungen Untersuchung zu Ikonographie, Inhalt und Komposition der Reliefs", In Fritz Hintze, ed., Musawwarat Es Sufra. Der Löwentempel, vol. 1: Textband, Berlin.

William, B., (1983). C-group, Pan-Grave and Kerma Remains at Adindan Cemeteries T, K, V, Chicago.

Winlock, E., (1928). "The Egyptian Expedition 1927-1928: The Museum's Excavations at Thebes", BMMA 23.

https://www.metmuseum.org/art/collection/search/591235? exhibitionId= \%7B36BFD863-BD71-4D58-B1B2-

F3F865084DBB\%7D\&oid $=591235 \& p k g i d s=331 \& p g=4 \& r p p=20 \& p$ os $=65 \& \mathrm{ft}^{*}=$ accessed on Jan 2018.

https://www.brooklynmuseum.org/opencollection/objects/3607 accessed on Jan 2018.

\section{Figures:}
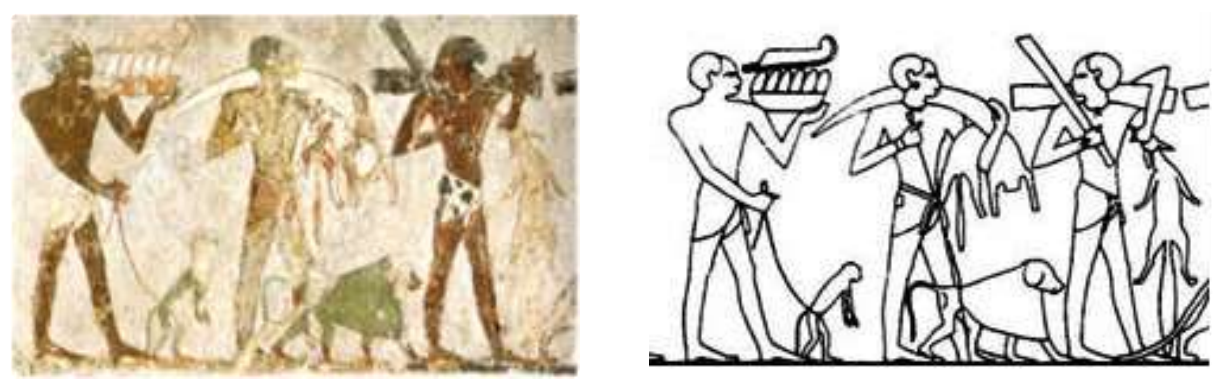

Fig. 1 The leather loincloth

Rekmire tomb (TT 100), New Kingdom Davies Norman \& Nina, (1935). op.cit, pl. XXII/1

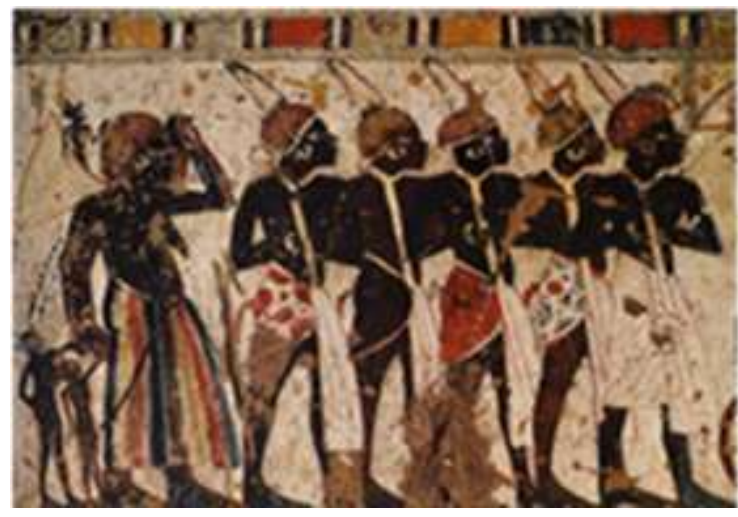

Fig. 2 Nubian Tribute providers with bag-Tunic and remarkable sash Huy tomb (TT 40), New Kingdom Barry J. Kemp., (2005). Ancient Egypt, p. 35 
Fig. 4 A brick maker wearing leather loincloth

Rekmire tomb, (TT 100), New

Kingdom

Strouhal, E., (1992). Life of Ancient Egyptians, fig. 71
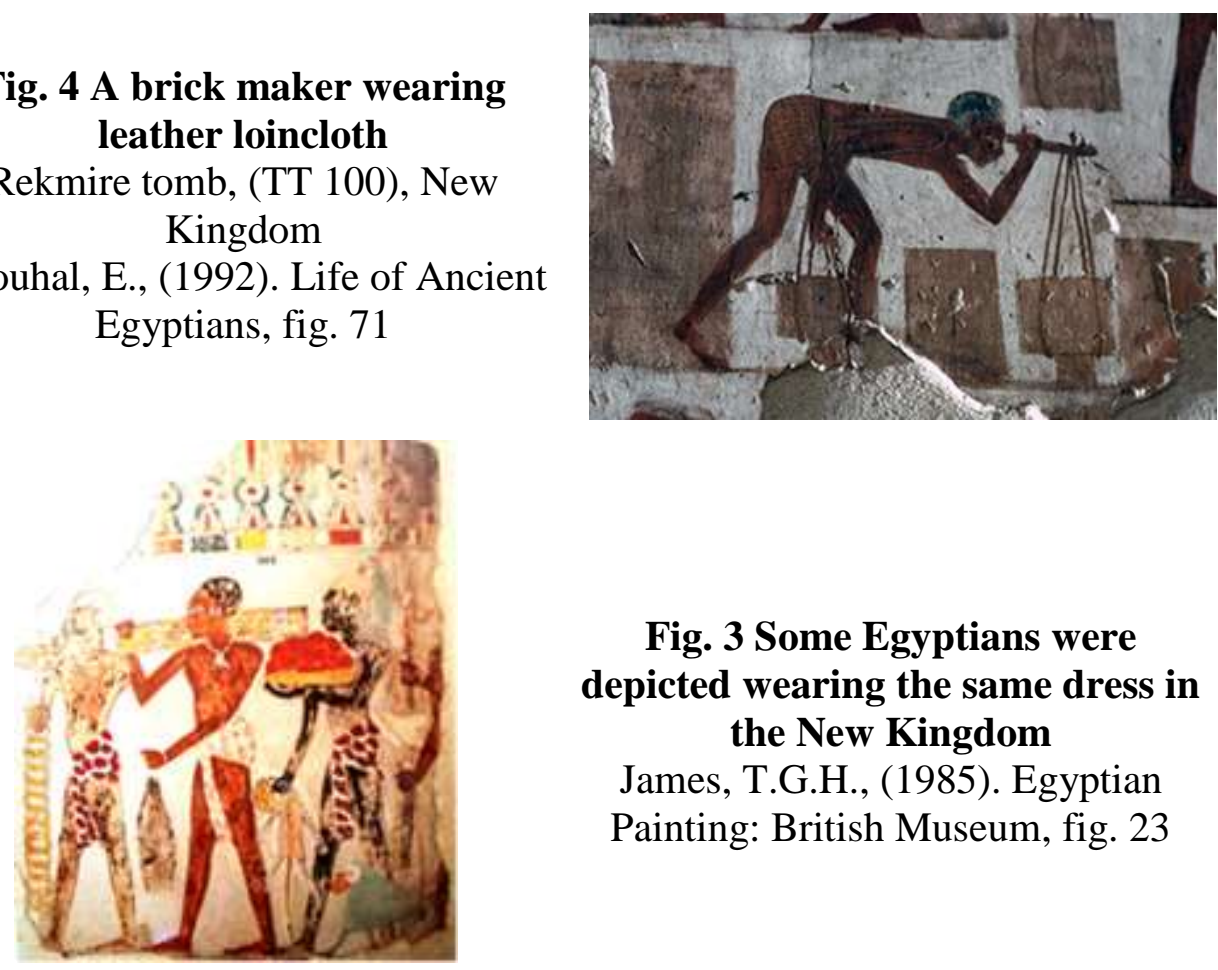

Fig. 3 Some Egyptians were depicted wearing the same dress in the New Kingdom James, T.G.H., (1985). Egyptian Painting: British Museum, fig. 23
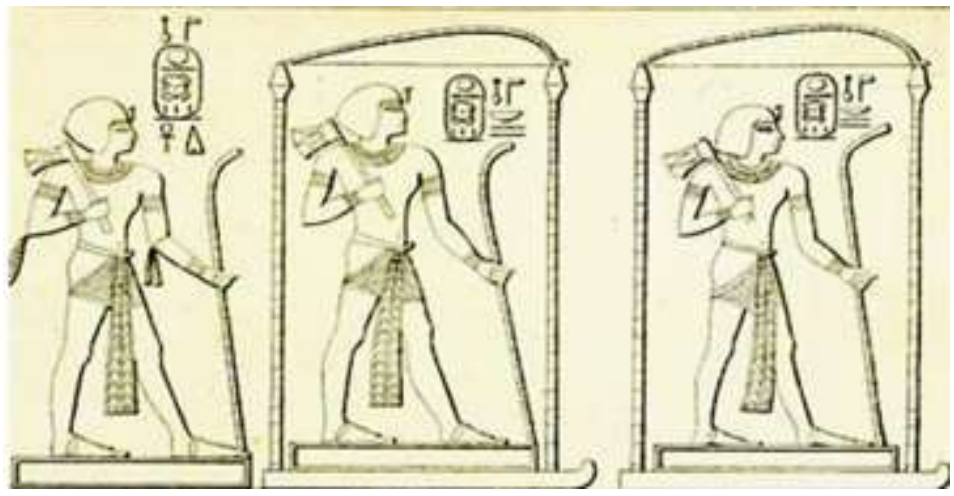

Fig. 5 King Amenhotep II wearing leather loincloth $18^{\text {th }}$ Dynasty, New Kingdom, Qen-Amūn tomb (TT 93), Thebes Lespsus, V, Abt, III, Bl. 64.a. 


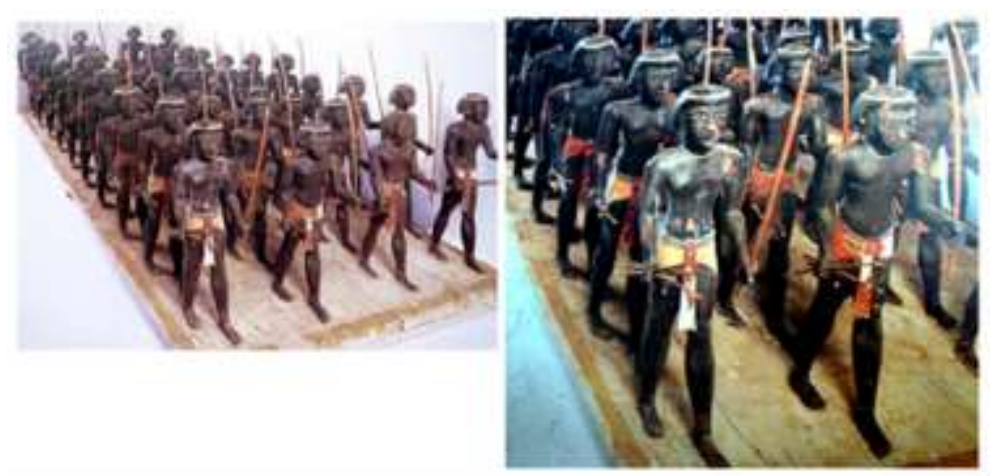

Fig. 6 Nubian mercenaries

Middle Kingdom

Saleh, M -Sourouzian, H., (1987). op. cit, nr. 72

Fig. 8 Men depicted in the battle scenes, $11^{\text {th }}$ Dynasty

Antef tomb

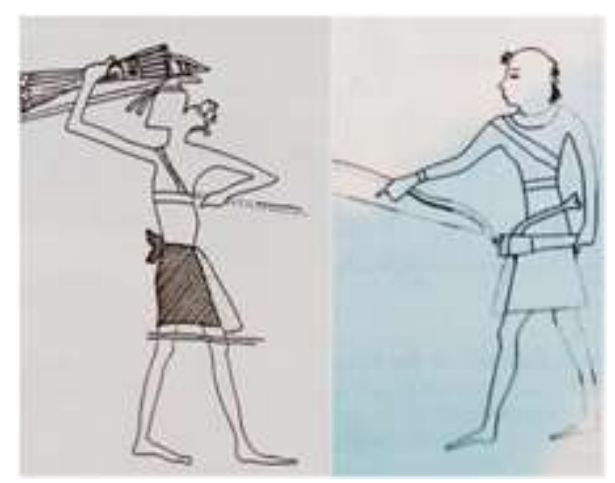

Fig. 7 Nubians in Egyptian depictions predating the $25^{\text {th }}$ Dynasty wear an apron as a decorative item over another cloth.

Fischer, H.G., (1961). The Nubians Mernceries at Gebelein during 1st Intermediate", Kush IX, pp. 44- 80.

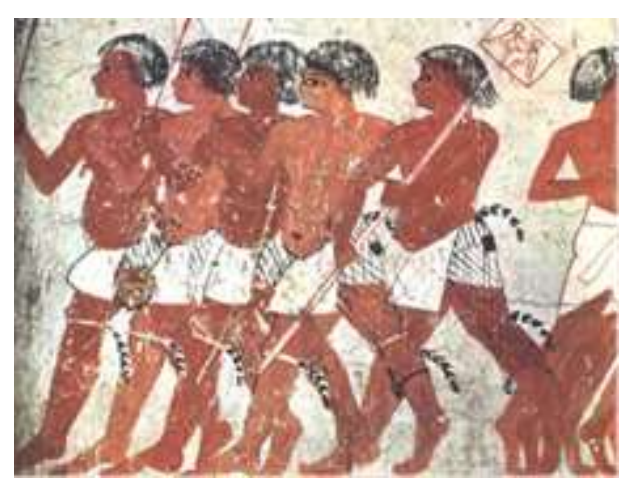




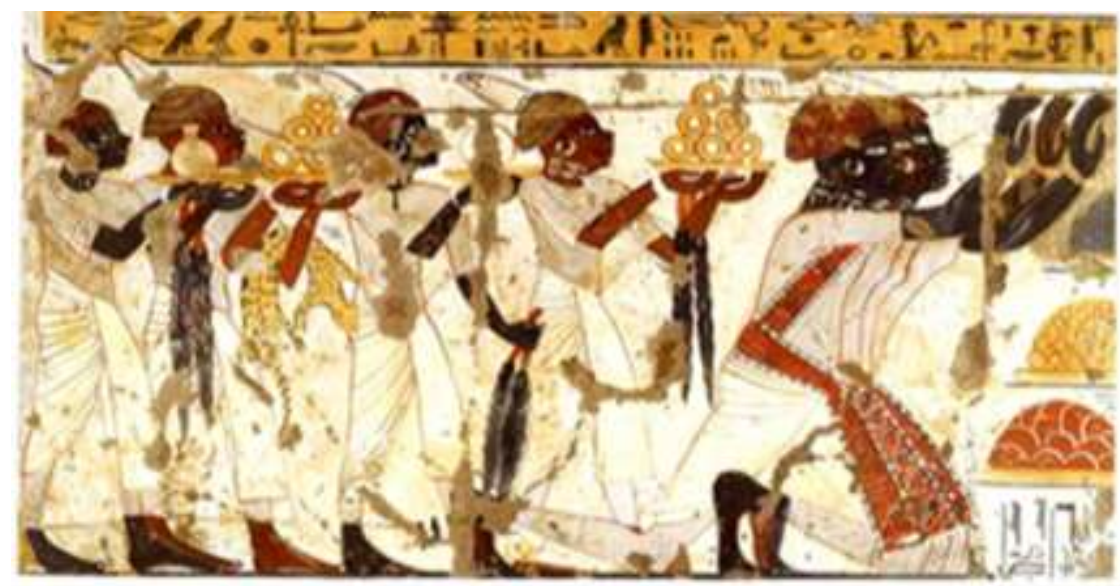

Fig. 9 Nubian clothing that appears before $25^{\text {th }}$ Dynasty. The broad sash of bag-tunic with geometrical length sash wrapped around the waist like the belt then hangs down

Huy tomb (TT 40)

Barry J. Kemp., (2005). Ancient Egypt, p. 35

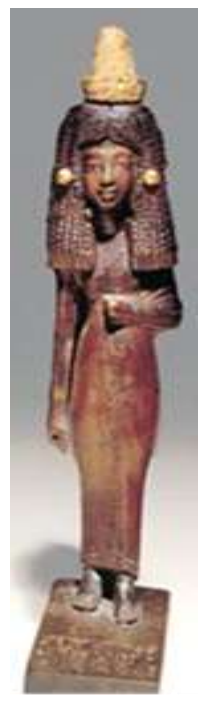

Fig. 10 Statue of a Nubian woman Tuty, Tomb at Medinet Gurob Amarna Period

Brooklyn Museum

https://www.brooklynmuseum.org/ opencollection/objects/3607

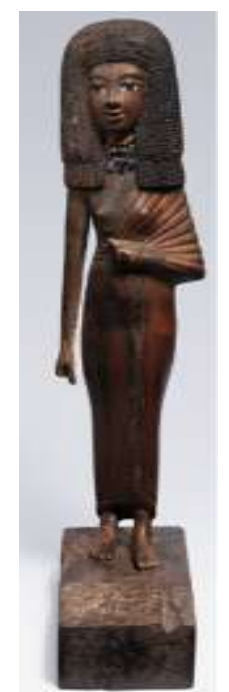

Fig. 10 a Statue of a Nubian woman Tiye Amarna Period, Metropolitan Museum of Art Arnold. D., (1996). The Royal Women of Amarna: Images of Beauty from Ancient Egypt, The Metropolitan Museum of Art, p. 27, fig. 20. 


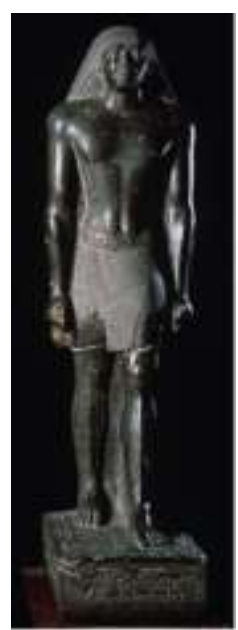

Fig. 11 Mentuemhat wearing the royal kilt with apron after the fashion of the Old Kingdom rulers

Egyptian Museum, Cairo

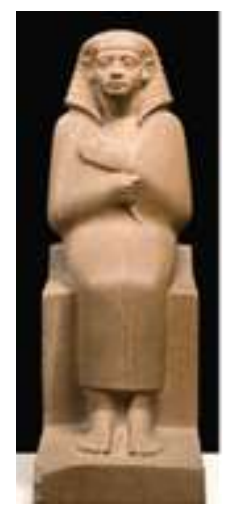

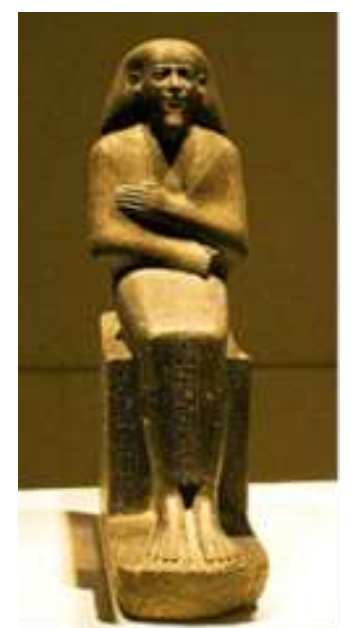

Fig. 12 Mentuemhat appears with the wrap-around cloak

Neues Museum, Berlin

Fig. 13: Statue of the Sealer Nemtihotep Seated wearing individual costume

Middle Kingdom, From El-Burj el Hamam (near Asyut)

https://www.metmuseum.org/art/collection/s earch/591235? exhibitionId=\%7B36BFD863BD71-4D58-B1B2-

F3F865084DBB\%7D\&oid=591235\&pkgids $=331 \& p g=4 \& \mathrm{rpp}=20 \& \mathrm{pos}=65 \& \mathrm{ft}=*$

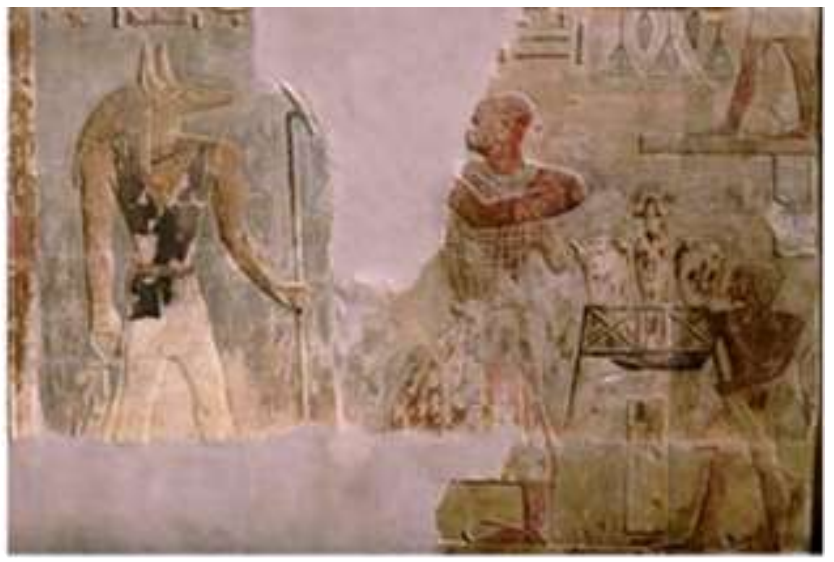

Fig. 14 Mentuemhat and Anubis

Thebes, late $25^{\text {th }}$ to early $26^{\text {th }}$ Dynasty

Nelson-Atkins Museum of Art 

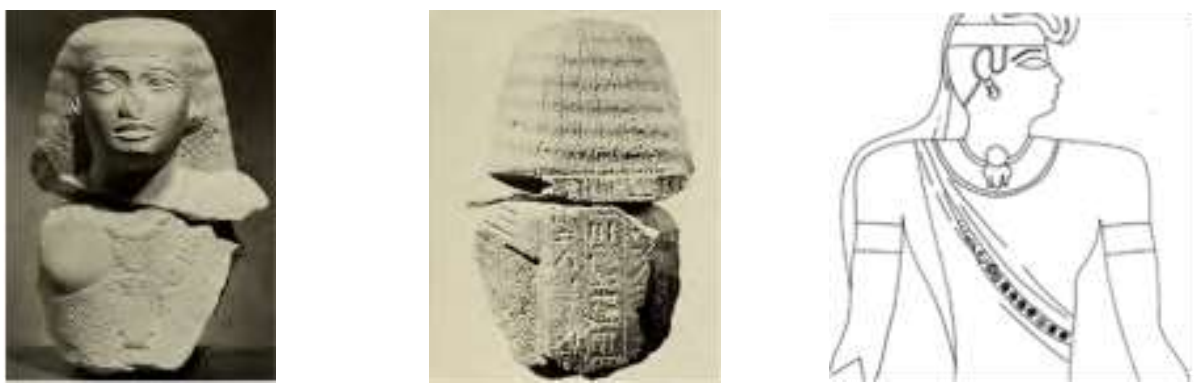

Fig. 15 This dotted-rosette decorative pattern is repeated on a statue of Mentuemhat

Fig. 16 The rosette on Tantamani's cloak
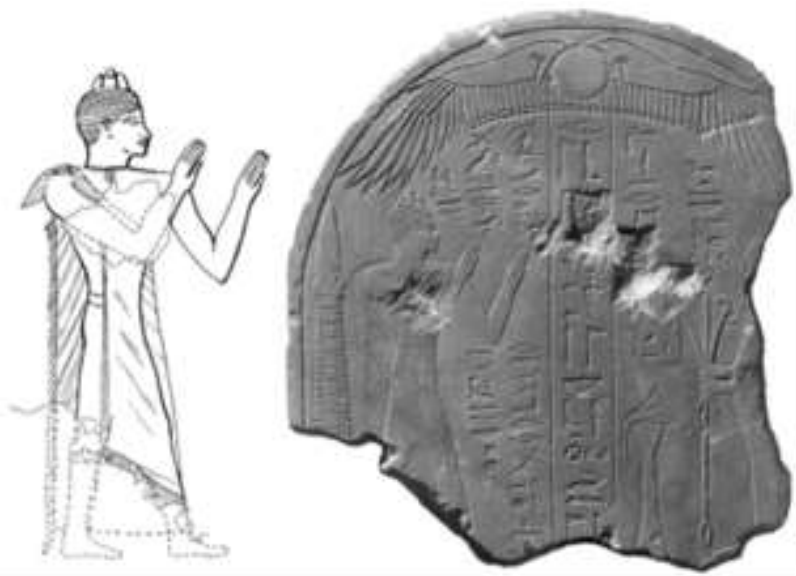

Figure 17 Pekartror shown wearing a transparent cloak that leaves his left shoulder free

Stela of Pekartror, OIM 6408, Cemetery D, tomb 9Abydos

Hallmann, A., (2007) The "Kushite Cloak", JARCE 43, pp. 15- 27, fig 1.
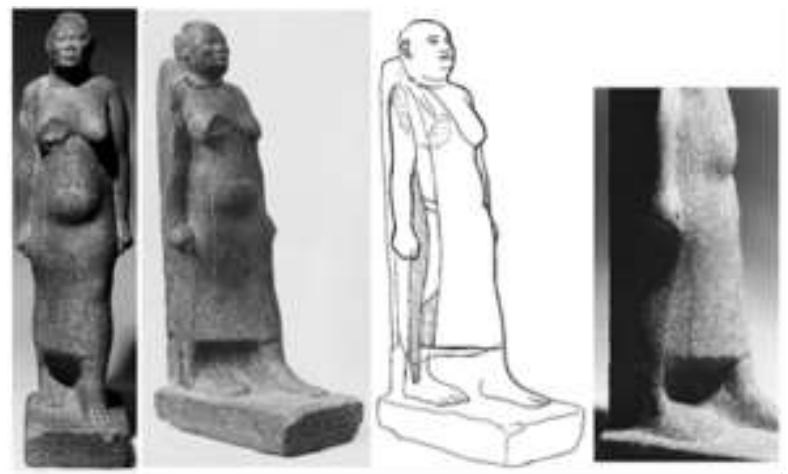

Fig. 18 Statue of Iriketakana

Egyptian Museum in Cairo JE38018 but now in Nubian museum, Aswan Hallmann, A., (2007) op .cit, pp. 15- 27, fig 2. 


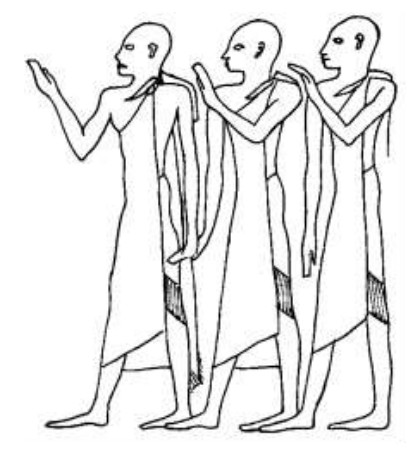

Figure 19 Men worn a cloak like Pekartror

Stela JE 21972

Hallmann, A., (2007) op .cit, fig 6.

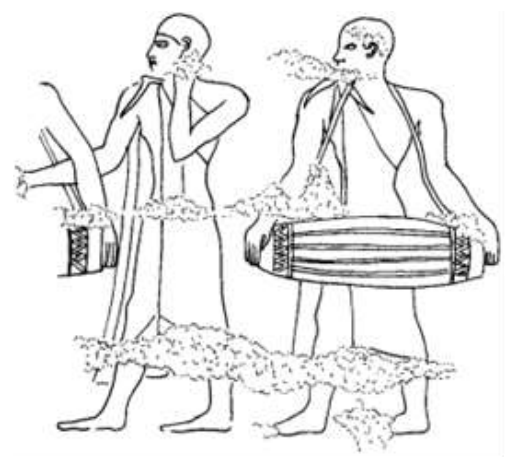

Fig. 20 Kushite musicians

Taharqa's temple in Kawa

Hallmann, A., (2007) op .cit, fig 5.

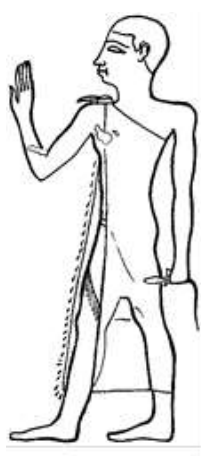

Figure 19 a Man, with cloak, in stela in Egyptian Museum, Cairo JE 21972.

Hallmann, A., (2007) op .cit, fig 5.

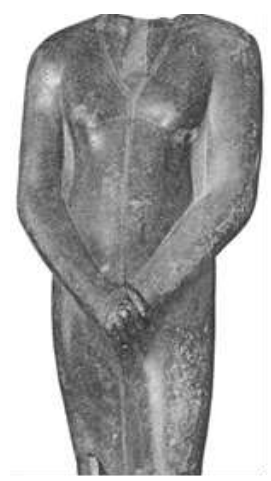

Fig. 21 Amenhotep III wear the cloak drapes over one shoulder, New Kingdom

Fahim, T., (2012) op. cit, fig 124 